\title{
Long-term Infusion of Growth Hormone Release Inhibiting Hormone in Acromegaly: Effects on Pituitary and Pancreatic Hormones
}

\author{
G. M. BESSER, C. H. MORTIMER, \\ A. S. MCNEILLY, \\ M. O. THORNER, \\ G. A. BATISTONI, \\ S. R. BLOOM, K. W. KASTRUP, K. F. HANSSEN, R. HALL, D. H. COY, A. J. KASTIN, \\ A. V. SCHALLY
}

British Medical fournal, 1974, 4, 622-627

\begin{abstract}
Summary
Growth hormone release inhibiting hormone (GH-RIH) was infused at a rate of $1.3 \mu \mathrm{g} / \mathrm{min}$ for $28 \mathrm{hours}$ into four patients with acromegaly, two of whom also had clinical diabetes mellitus. Growth hormone and glucagon were suppressed throughout the infusion though delayed secretion of insulin occurred in association with both meals and an oral glucose load. Glucose tolerance was improved in one diabetic patient who was taking chlorpropamide while the other required much less insulin than usual. Secretion of endogenous thyroid-stimulating hormone was lowered in one euthyroid patient on carbimazole. Luteinizing hormone, follicle-stimulating hormone, ACTH, and prolactin were not affected. Serum somatomedin levels were reduced in one patient. There was a rapid rebound of all the suppressed hormones when the infusions stopped. Longer-acting analogues of GH-RIH will be needed before long-term therapy of acromegaly or diabetes mellitus becomes possible, but such preparations should be available soon for clinical trial.
\end{abstract}

\section{Introduction}

We have previously shown that short-term infusions of growth hormone release inhibiting hormone (GH-RIH) are effective in man in suppressing growth hormone (GH) (Hall et al., 1973; Besser et al., 1974; Mortimer et al., 1974), glucagon and insulin (Mortimer et al., 1974), and the thyrotrophin and folliclestimulating hormone( $\mathrm{TSH}$ and $\mathrm{FSH}$ ) responses after intravenous-

St. Bartholomew's Hospital, London EC1A 7 BE

G. M. BESSER, M.D., F.R.C.P., Professor of Endocrinology, Medical Professorial Unit

C. H. MORTIMER, M.B., M.R.C.P., Research Lecturer in Medicine

A. S. MCNEILLY, PH.D., Research Lecturer in Chemical Pathology

A. S. MCNEILLY, PH.D., Research Lecturer in Chemical Pathology

M. O. THORNER, M.B., M.R.C.P., Research Lecturer in Medicine
G. A. BATISTONI, B.PHARM., M.P.S., Analytical Research Pharmacist

Department of Medicine, Middlesex Hospital, London W.1

S. R. BLOOM, M.B., M.R.C.P., Research Fellow

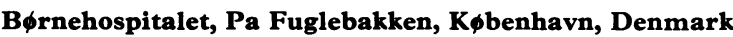

K. W. KASTRUP, M.D., Consultant Paediatrician

Steno Memorial Hospital, Gentofte, Denmark

K. F. HANSSEN, M.D., Medical Registrar (Present address: University Department of Medicine B, Aker Sykehus, Oslo, Norway)

Department of Medicine, Royal Victoria Infirmary, Newcastle upon Tyne

R. HALL, M.D., F.R.C.P., Professor of Medicine

Veterans Administration Hospital and Department of Medicine, Tulane University School of Medicine, New Orleans, U.S.A.

D. H. COY, PH.D., Assistant Professor of Medicine

A. J. KASTIN, M.D., Professor of Medicine

A. V. SCHALLY, PH.D., Professor of Medicine injection of the thyrotrophin-releasing hormone (TRH) (Hall et al., 1973): during an infusion of GH-RIH a diabetic patient with a glucagon-secreting tumour was rendered hypoglycaemic (Mortimer et al., 1974). Some of these effects have been confirmed by others (Siler et al., 1973; Hansen et al., 1973; Alberti et al., 1973; Siler et al., 1974).

The effect of GH-RIH given as bolus injections is short lived. For this reason infusions have been used and the longest studies so far described have been over four hours (Besser et al., 1974; Mortimer et al., 1974). This preliminary work led to the study of the effects of long-term infusions of GH-RIH in patients with acromegaly with or without diabetes mellitus to determine whether this hormone was effective over a prolonged period of time and to observe any beneficial or adverse effects in the control of GH secretion or glucose tolerance. The circulating levels of the other pituitary hormones and somatomedin were also measured. In addition GH-RIH was combined with protamine zinc in an attempt to produce a depot preparation and its actions were studied.

\section{Patients}

Two male and two female patients aged 50 to 65 years were studied. All had evidence of active acromegaly. Two had previously had external pituitary irradiation, one a transfrontal partial hypophysectomy, and the fourth patient was untreated. Two patients had clinical diabetes mellitus, a woman being treated with oral chlorpropamide $500 \mathrm{mg}$ /day (case 1) and a man receiving $102 \mathrm{U} /$ day of soluble insulin in divided doses (case 2 ). One woman also had thyrotoxicosis but was euthyroid at the time of study on treatment with carbimazole $10 \mathrm{mg} /$ day (case 4). Both females were post-menopausal with high levels of circulating gonadotrophins. All the participants were informed volunteers who gave their written consent.

\section{Methods}

\section{GH-RIH INFUSIONS}

The normal dietary intake of each patient was assessed before the study began and was then kept constant throughout the period of investigation. Each patient was studied as follows: day 1 (starting at 08.30)-a glucose tolerance test (G.T.T.) was performed during a control infusion of $0.9 \% \mathrm{NaCl}$; blood samples were withdrawn half an hour before, at zero time, and then half hourly for three hours after an oral load of $50 \mathrm{~g}$ glucose; day $2(12.00)$-during a control infusion of $0.9 \% \mathrm{NaCl}$ blood was sampled one hour before and hourly for four hours during and after a normal lunch, and the "lunch curve" was estimated; day $3(08.00)-$ GH-RIH was infused for 28 hours at a rate of $1.3 \mu \mathrm{g} / \mathrm{min}$ since this had been found to be the minimum effective dose for lowering $\mathrm{GH}$ levels in acromegaly in earlier studies (Besser et al., 1974). Patients were connected to a constant infusion pump via a $200-\mathrm{cm}$ catheter so that the patients could be out of bed during the day. Blood was sampled throughout the 28 hours. A lunch curve was obtained during the first day of the GH-RIH infusion and the oral G.T.T. was repeated at 08.00 
on the second morning of the infusion so that comparisons could be made with the control infusions.

Blood samples were withdrawn via an indwelling venous cannula introduced at least 30 minutes before sampling. Samples were also taken hourly for five hours and at 24 hours after the GH-RIH infusions had stopped. These were assayed for plasma GH, glucose, glucagon, insulin, serum TSH, corticosteroids, luteinizing hormone ( $\mathrm{LH})$, follicle-stimulating hormone ( $\mathrm{FSH}$ ), prolactin, and somatomedin. Urine was collected during the control and GH-RIH infusions in four-hour periods until midnight and as an eight-hour overnight collection for measurement of $\mathrm{GH}$ excretion.

The two women also had blood samples withdrawn through an indwelling venous cannula throughout a 28-hour control period when not receiving GH-RIH to compare the levels of serum TSH, prolactin, LH, FSH, and cortisol with an infusion day. In one patient this was performed the day before GH-RIH infusion and in the other three weeks after the completion of the initial studies.

$G H-R I H .-T h e$ cyclic tetradecapeptide was synthesized and purified as previously described by Coy et al. (1973).

\section{PROTAMINE ZINC GH-RIH}

Protamine zinc GH-RIH (PZ/GH-RIH) was prepared in an amorphous suspension in sodium phosphate buffer at $\mathrm{pH}$ 6.9-7.3 with phenol as a preservative according to the method described for the preparation of protamine zinc insulin (British Pharmacopoea, 1973). Each 0.5-ml ampoule of the suspension contained $0 \cdot 125 \mathrm{mg}$ of zinc together with $500 \mu \mathrm{g} \mathrm{GH}-\mathrm{RIH}$. $\mathrm{PZ} / \mathrm{GH}-\mathrm{RIH} 500 \mu \mathrm{g}$ was injected subcutaneously into the same acromegalic subject who had received intravenous, subcutaneous, and intramuscular injections of the same dose of GH-RIH and who has been reported previously (Besser et al., 1974). Two of the acromegalic patients from this study received PZ/GH-RIH $500 \mu \mathrm{g}$ subcutaneously at four-hour intervals. GH levels were followed for 12 hours in these patients.

\section{ASSAYS}

The following were measured by specific radioimmunoassay: plasma GH using M.R.C. 69/46 as standard (Forsyth et al., 1971), urinary GH by the method of Hanssen (1972), plasma pancreatic glucagon (C-terminal antiserum) with M.R.C. standard 69/104 (Bloom, 1971), serum insulin with M.R.C. standard 66/304 (Sönksen et al., 1973), serum TSH with M.R.C. standard 69/38 (Hall et al., 1973), serum prolactin with Friesen standard (McNeilly, 1973), serum LH with M.R.C. standard 68/40, and FSH with M.R.C. standard 68/39 (Mortimer et al., 1973). Serum corticosteroids were measured by a competitive protein-binding method (Baum et al., 1974) and plasma glucose by a neocuprine method (Technicon). Serum somatomedin was measured using a modified chick bioassay (Hall, 1971); normal levels are equivalent to the activity of $1 \mathrm{ml}$ of reference serumthat is, 1 unit-and differences of 0.15 units or more are significant.

\section{Results}

\section{PLASMA GROWTH HORMONE}

The mean basal GH levels in these four patients were $54,74,117$, and $158 \mathrm{ng} / \mathrm{ml}$. During the control studies the striking feature was the great surges of $\mathrm{GH}$ seen during the lunch and G.T.T. sampling period. The plasma $\mathrm{GH}$ after lunch on the control day rose to $135,125,256$, and $300 \mathrm{ng} / \mathrm{ml}$ respectively, while during the G.T.T. GH levels reached 66, 146, 290, and $300 \mathrm{ng} / \mathrm{ml}$. By contrast, during the infusion of GH-RIH, GH fell to minimum levels of $18,7,28$, and $38 \mathrm{ng} / \mathrm{ml}$ and the maximum values seen after food or glucose administration were 41, 26, 60, and 100 $\mathrm{ng} / \mathrm{ml}$ respectively. The levels rose rapidly, however, when the infusions were discontinued and maximum values during the five hours after the infusion had stopped were considerably higher than the basal levels $(120-376 \mathrm{ng} / \mathrm{ml})$. Twenty-four hours after the end of the infusion they were still raised with levels between $75 \mathrm{ng}$ and $460 \mathrm{ng} / \mathrm{ml}$. The basal values and the surges in $\mathrm{GH}$ in response to food and glucose were clearly suppressed during the infusion of GH-RIH (fig. 1).

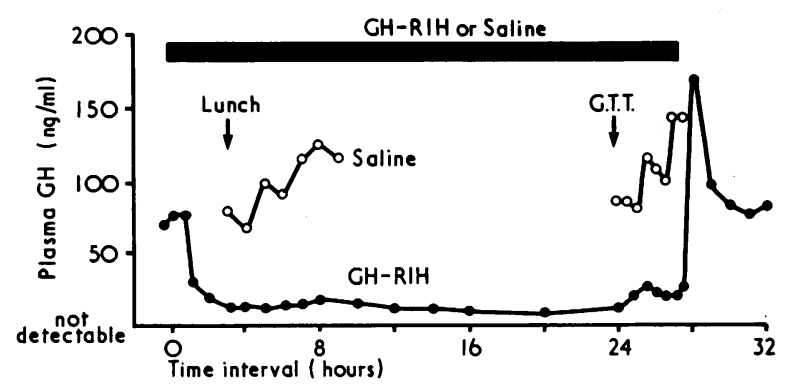

FIG. 1-Case 4. Effect of infusion of GH-RIH on plasma GH levels compared with saline control.

\section{URINARY GROWTH HORMONE}

Urinary $\mathrm{GH}$ excretion was measured as an indication of $\mathrm{GH}$ production. The total 24-hour urinary $\mathrm{GH}$ output in the patient illustrated in fig. 2 (case 4) was $1,050 \mathrm{ng}$ (normal range 37-84 $\mathrm{ng} / 24 \mathrm{hr}$ ), about half of that being excreted during the night. The urinary GH output during the 28 hours of the GH-RIH infusion was greatly reduced $(268 \mathrm{ng} / 28 \mathrm{hr}$ ), with a clear reduction in the overnight excretion. There was a partial recovery in urinary $\mathrm{GH}$ excretion in the 24 hours after the infusion of $\mathrm{GH}-\mathrm{RIH}$ ( $467 \mathrm{ng} / 24 \mathrm{hr}$ ). The other three patients had urinary GH measured only between 08.00 and 24.00 hours on the day before, the day of, and the day after the GH-RIH infusion (table I). The results confirm that the infusion of GH-RIH reduced urinary GH levels throughout the day time though an increase in excretion occurred after its cessation. Urinary GH excretion therefore followed closely the changes in plasma GH levels.

TABLE I-Urinary GH Secretion (ng) before, during, and after GH-RIH Infusions in Three Acromegalic Patients

\begin{tabular}{c|c|c|c}
\hline Case No. & Day before GH-RIH & Day of GH-RIH & Day after GH-RIH \\
\cline { 2 - 3 } & 177 & 138 & 184 \\
2 & 285 & 112 & 156 \\
3 & 163 & 87 & 261 \\
\hline Mean & 208.3 & 112.3 & $200 \cdot 3$ \\
\hline
\end{tabular}

\section{SERUM SOMATOMEDIN}

Serum somatomedin levels were significantly raised in two patients and normal in the others (table II). The patient in case 1 had a normal basal level of 1.02 units which fell significantly to a minimum value of 0.83 units at 26 hours and was still depressed at 28 hours (0.91 units). The level returned to 1.01 units 24 hours after the end of the infusion. The other patients did not show significant suppression of serum somatomedin levels.

TABLE II-Serum Somatomedin Levels (Somatomedin $U / \mathrm{ml}$ ) before, during, and after 28-hour Infusion of GH-RIH in Four Acromegalic Patients

\begin{tabular}{l|c|c|c|c|c|c|c|c}
\hline \multicolumn{1}{c|}{ Time (hr) } & 0 & 6 & 12 & $24 \frac{1}{2}$ & 26 & 28 & 32 & 48 \\
\hline Case 1 & 1.02 & 1.06 & 0.97 & 1.0 & $0.83 \dagger$ & $0.91 \dagger$ & 0.94 & 1.01 \\
Case 2 & 1.28 & 1.44 & 1.33 & 1.36 & 1.3 & 1.46 & 1.21 & 1.57 \\
Case 3 & 0.99 & 1.08 & 1.19 & 1.00 & 0.99 & 1.01 & 0.93 & 1.03 \\
Case 4 & 1.10 & $1.17 *$ & 1.22 & 1.18 & 1.28 & & 1.36 & 1.15 \\
\hline
\end{tabular}

*Value at four hours.
†Significantly less than basal value $(P<0.05)$. 


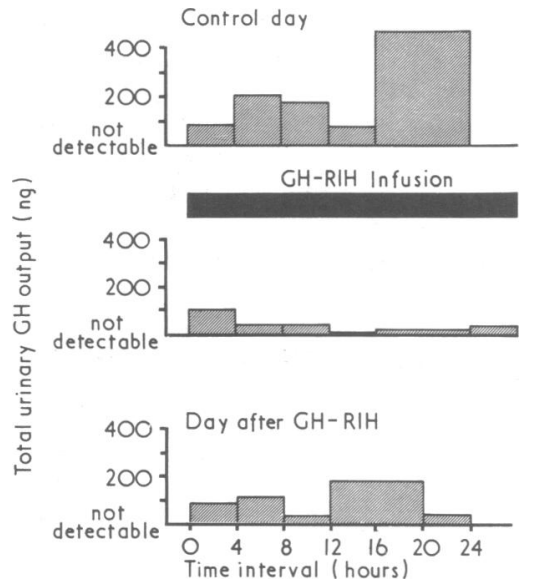

FIG. 2-Case 4. Effect of infusion of GH-RIH on total urinary GH excretion.

\section{PLASMA GLUCAgON}

Basal plasma glucagon levels ranged from 27 to $72 \mathrm{pg} / \mathrm{ml}$. These were suppressed throughout the period of the infusion of GH-RIH to $6-30 \mathrm{pg} / \mathrm{ml}$, and when the infusion ceased levels rebounded to $49-206 \mathrm{pg} / \mathrm{ml}$ in the next five hours. Twenty-four hours after the infusion the levels were from 51 to $72 \mathrm{pg} / \mathrm{ml}$. Levels were much higher on the control day during the lunch curve in all four subjects, maximal levels reaching 63 to 93 $\mathrm{pg} / \mathrm{ml}$, but when GH-RIH was infused the levels were from 3 to $47 \mathrm{pg} / \mathrm{ml}$. Glucagon levels seemed to be reduced during the first hour of the G.T.T. in three of the four patients and thereafter there was evidence of breakthrough secretion in two of them. Clearly, therefore, GH-RIH suppressed glucagon secretion basally and postprandially, but not consistently after a glucose load (fig. 3, tables III and IV).

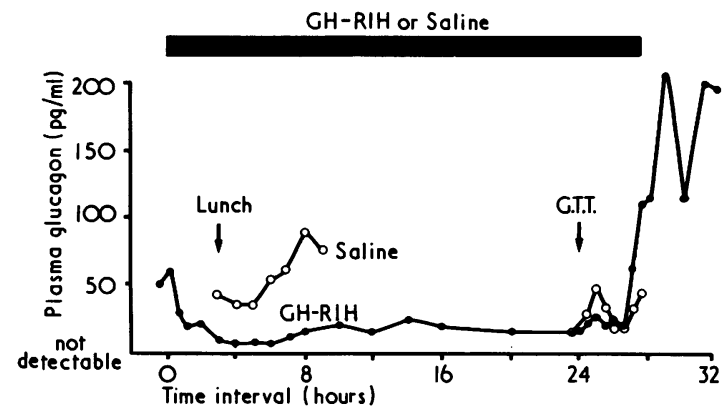

FIG. 3-Case 4. Effect of infusion of GH-RIH on plasma glucagon levels compared with saline control.

\section{PLASMA INSULIN}

Basal plasma insulin levels ranged from 20.5 to $45 \mu \mathrm{U} / \mathrm{ml}$ in three subjects. Insulin was not assayed in the patient on soluble insulin. In three patients levels fell during the initial infusion of GH-RIH to $6 \cdot 0-11 \cdot 3 \mu \mathrm{U} / \mathrm{ml}$. During the lunch period on the control infusion day the levels rose to maximum values of 115 and $>500 \mu \mathrm{U} / \mathrm{ml}$ in two subjects and $73.7 \mu \mathrm{U} / \mathrm{ml}$ in the patient on chlorpropamide compared to values of 73,121 , and 24.5 $\mu \mathrm{U} / \mathrm{ml}$ on the day of GH-RIH. Similarly, basal levels before the G.T.T. was performed during the GH-RIH infusion were 9, 49, and $16.7 \mu \mathrm{U} / \mathrm{ml}$ but these rose to a maximum level of $>250$, $>150$, and $27 \cdot 3 \mu \mathrm{U} / \mathrm{ml}$ respectively after the ingestion of $50 \mathrm{~g}$ of glucose. Corresponding maximum values on the control day were 149,176 , and $99 \mu \mathrm{U} / \mathrm{ml}$. It was evident, therefore, that there was a delayed breakthrough secretion of insulin in response to a normal lunch or oral glucose load though GH and glucagon secretion were suppressed. In one subject the breakthrough resulted in higher levels of insulin being achieved during the G.T.T. despite the infusion of GH-RIH (fig. 4).

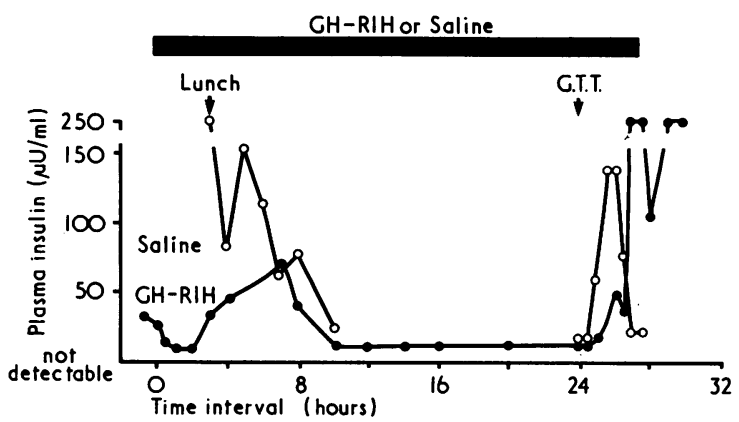

FIG. 4-Case 4. Effect of infusion of GH-RIH on plasma insulin levels compared with saline control.

TABLE III-Plasma Glucagon Levels (pg/ml) in Four Acromegalic Patients during Lunch on Control Saline and GH-RIH Infusions

\begin{tabular}{|c|c|c|c|c|c|c|c|}
\hline \multirow{2}{*}{ Case No. } & \multicolumn{7}{|c|}{ Time (hr) } \\
\hline & -1 & 0 & 1 & 2 & 3 & 4 & 6 \\
\hline 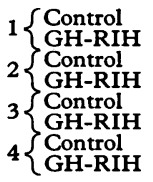 & $\begin{array}{r}58 \\
30 \\
32 \\
19 \\
53 \\
19 \\
41 \\
6\end{array}$ & $\begin{array}{r}56 \\
32 \\
34 \\
16 \\
52 \\
12 \\
36 \\
3\end{array}$ & $\begin{array}{r}60 \\
47 \\
64 \\
25 \\
63 \\
23 \\
34 \\
6\end{array}$ & $\begin{array}{r}64 \\
38 \\
43 \\
18 \\
45 \\
17 \\
52 \\
5\end{array}$ & $\begin{array}{r}76 \\
37 \\
44 \\
15 \\
47 \\
15 \\
60 \\
9\end{array}$ & $\begin{array}{l}93 \\
30 \\
35 \\
17 \\
43 \\
16 \\
90 \\
14\end{array}$ & $\begin{array}{l}56 \\
31 \\
33 \\
22 \\
36 \\
26 \\
75 \\
18\end{array}$ \\
\hline
\end{tabular}

TABLE IV-Plasma Glucagon Levels ( $\mathrm{g} / \mathrm{ml}$ ) in Four Acromegalic Patients during Oral Glucose Tolerance Tests on Control Saline and GH-RIH Infusions

\begin{tabular}{|c|c|c|c|c|c|c|c|c|}
\hline \multirow{2}{*}{ Case No. } & \multicolumn{8}{|c|}{ Time (min) } \\
\hline & 30 & 0 & 30 & 60 & 90 & 120 & 150 & 180 \\
\hline 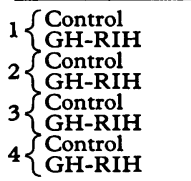 & $\begin{array}{l}48 \\
49 \\
32 \\
26 \\
44 \\
63 \\
16 \\
16\end{array}$ & $\begin{array}{l}42 \\
58 \\
26 \\
42 \\
62 \\
65 \\
28 \\
20\end{array}$ & $\begin{array}{l}38 \\
83 \\
36 \\
32 \\
60 \\
38 \\
49 \\
20\end{array}$ & $\begin{array}{l}55 \\
55 \\
35 \\
28 \\
48 \\
35 \\
32 \\
19\end{array}$ & $\begin{array}{l}41 \\
43 \\
16 \\
21 \\
35 \\
35 \\
17 \\
24\end{array}$ & $\begin{array}{l}30 \\
65 \\
27 \\
30 \\
36 \\
44 \\
14 \\
16\end{array}$ & $\begin{array}{l}37 \\
41 \\
29 \\
28 \\
26 \\
51 \\
33 \\
62\end{array}$ & $\begin{array}{r}28 \\
38 \\
23 \\
28 \\
50 \\
107 \\
42 \\
111\end{array}$ \\
\hline
\end{tabular}

\section{PLASMA GLUCOSE}

\section{During the Lunch Curve}

Basal levels of plasma glucose were measured at 11.00 and 12.00 hours on both the control and infusion days, then lunch was eaten. On the infusion day GH-RIH had been infused contin- $N$ uously from 08.00 hours. In cases 1,3 , and 4 basal levels were $N$ higher on the GH-RIH day-by 46, 30, and $69 \mathrm{mg} / 100 \mathrm{ml}-$ compared with the control, whereas in case 2 the levels were lower by $42 \mathrm{mg} / 100 \mathrm{ml}$ (table V). The peaks reached after GH-RIH were higher in cases 1,3 , and 4 by 41,58 , and 29 $\mathrm{mg} / 100 \mathrm{ml}$ than on control saline but were the same in case 2 .

\section{Oral G.T.T.}

The result of the glucose tolerance test in case 1 was improved by GH-RIH. This patient in this case was the female diabetic who was being treated with chlorpropamide and who continued on this treatment throughout the study. The diabetic man on a $150-\mathrm{g}$ carbohydrate diet, who was normally controlled with 102 units/day of soluble insulin (case 2), received 30 units of soluble insulin subcutaneously at $08.00,12.00$, and 18.00 hours on the two control days. On the GH-RIH day he had only 
TABle v-Plasma Glucose Levels in Four Acromegalic Patients

\begin{tabular}{|c|c|c|c|c|c|}
\hline \multirow[b]{2}{*}{ Case No. } & \multicolumn{2}{|c|}{ Lunch Curve } & \multicolumn{3}{|c|}{ Glucose Tolerance } \\
\hline & $\begin{array}{c}\text { Mean Basal Glucose } \\
(\mathrm{mg} / 100 \mathrm{ml})\end{array}$ & $\begin{array}{l}\text { Peak after Lunch } \\
(\mathrm{mg} / 100 \mathrm{ml})\end{array}$ & $\underset{(\mathrm{mg} / 100 \mathrm{ml})}{\text { Fasting }}$ & $\begin{array}{c}\text { Peak } \\
(\mathrm{mg} / 100 \mathrm{ml})\end{array}$ & $\begin{array}{l}\text { At } 3 \text { Hours } \\
(\mathrm{mg} / 100 \mathrm{ml})\end{array}$ \\
\hline 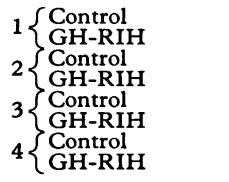 & $\begin{array}{l}168 \\
214 \\
213 \\
171 \\
180 \\
210 \\
124 \\
193\end{array}$ & $\begin{array}{l}163 \\
204 \\
187 \\
187 \\
196 \\
254 \\
135 \\
164\end{array}$ & $\begin{array}{l}209 \\
162 \\
161 \\
234^{*} \\
111 \\
119 \\
97 \\
107\end{array}$ & $\begin{array}{l}340 \\
287 \\
282 \\
280 \\
237 \\
246 \\
205 \\
163\end{array}$ & $\begin{array}{r}249 \\
207 \\
196 \\
226 \\
108 \\
101 \\
82 \\
107\end{array}$ \\
\hline
\end{tabular}

*Value after 24 hours off insulin.

one injection of 30 units subcutaneously at 08.00 hours at the start of the infusion. Though his basal plasma glucose levels were increased during GH-RIH infusion the peak response after an oral glucose load was little changed despite his receiving only one-third of his normal insulin requirements during that 24 hours. This patient did not in fact receive further insulin until 24 hours after the end of the infusion when the plasma GH level was $228 \mathrm{ng} / \mathrm{ml}$, plasma glucagon $22 \mathrm{pg} / \mathrm{ml}$, and plasma glucose $232 \mathrm{mg} / 100 \mathrm{ml}$ with glycosuria and ketonuria. In one non-diabetic patient (case 3) the glucose tolerance was little altered during the GH-RIH infusion except for a higher two-hour value, but this had fallen by two and a half hours. In the other nondiabetic patient (case 4) the peak plasma glucose was delayed during the GH-RIH infusion until 120 minutes at which time a level of $163 \mathrm{mg} / 100 \mathrm{ml}$ was recorded. This was less than during the control study (fig. 5).

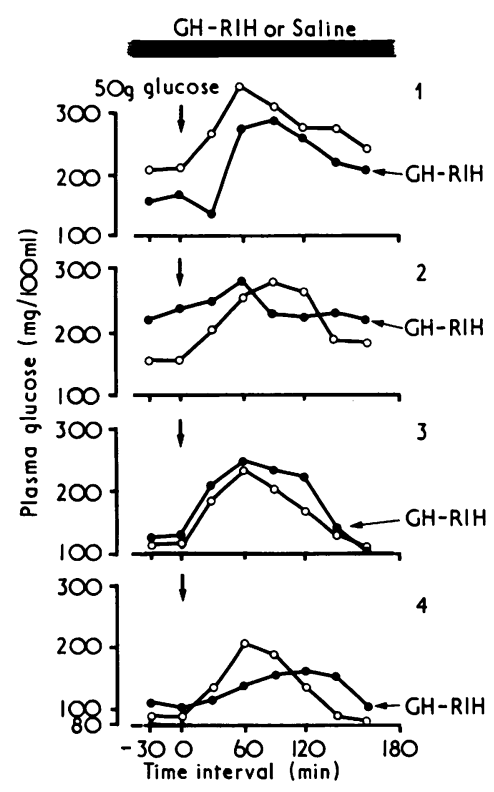

FIG. 5-Effect of infusion of GH-RIH (O) on plasma glucose levels compared with saline control (o) in patients with acromegaly and diabetes mellitus (cases 1 and 2) and acromegaly only (cases 3 and 4).

In cases 2,3 , and 4 the mean plasma glucose levels measured 24 and $24 \frac{1}{2}$ hours after the start of the GH-RIH infusion were higher by 73,8 , and $10 \mathrm{mg} / 100 \mathrm{ml}$ respectively but lower in the diabetic patient in case 1 by $47 \mathrm{mg} / 100 \mathrm{ml}$. The peak plasma glucose values achieved were greater by $9 \mathrm{mg} / 100 \mathrm{ml}$ in case 3 but lower by 53,2 , and $42 \mathrm{mg} / 100 \mathrm{ml}$ in cases 1,2 , and 4 during GH-RIH compared with the control studies. Three hours after the glucose load the levels were higher in cases 2 and 4 (by 30 and $25 \mathrm{mg} / 100 \mathrm{ml}$ ) but lower in cases 1 and 3 (by 42 and 7 $\mathrm{mg} / 100 \mathrm{ml}$ ).

When the 28-hour infusions of GH-RIH were stopped plasma glucose levels fell from 186 to $89 \mathrm{mg} / 100 \mathrm{ml}$ and from 97 to $89 \mathrm{mg} / 100 \mathrm{ml}$ in cases 2 and 3 respectively in the five hours after the infusions whereas in case 4 they rose from 57 to a maximum of $89 \mathrm{mg} / 100 \mathrm{ml}$.

\section{SERUM TSH}

Serum TSH levels were followed before, during, and after the infusion of GH-RIH in all four subjects. In three of them TSH levels ranged between undetectable $(<0 \cdot 4)$ and $4 \mu \mathrm{U} / \mathrm{ml}$ but since they were undetectable at various times throughout the study it was impossible to show any significant changes induced by the inhibiting hormone. One of the acromegalic female patients who had previously been thyrotoxic but was euthyroid on carbimazole at the time of study with normal serum thyroxine and triiodothyronine levels, however, had TSH levels above the normal range of $<0.4-4 \mu \mathrm{U} / \mathrm{ml}$. Her levels were between 5.0 and $7 \cdot 2 \mu \mathrm{U} / \mathrm{ml}$ on the control day and during the GH-RIH infusion they fell progressively (fig. 6). There was a clear rebound, however, when the infusion was discontinued. Since changes in serum TSH of $1 \mu \mathrm{U} / \mathrm{ml}$ or more are clearly significant the extent of the fall and the immediate rebound on stopping the GH-RIH infusion indicated that the TSH release was inhibited by GH-RIH.

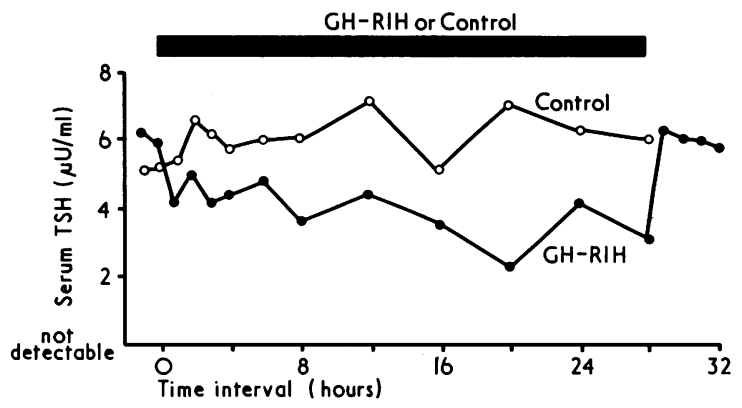

FIG. 6-Case 4. Effect of infusion of GH-RIH on serum TSH levels compared with control day in euthyroid acromegalic patient being treated with carbimazole for thyrotoxicosis.

TABLE vi-Plasma GH Levels (ng/ml) after Single Subcutaneous Injection of $500 \mu \mathrm{g}$ PZ/GH-RIH given at Time 0 to Acromegalic Patient who had Previously Received Same Dose Intravenously, Intramuscularly, and Subcutaneously combined with Arachis Oil or 16\% Gelatin (Besser et al., 1974) and in Cases 1 and 3 of this paper who received $500 \mu \mathrm{g} P Z / G H-R I H$ Subcutaneously every Four Hours

\begin{tabular}{|c|c|c|c|c|c|c|c|c|c|c|c|c|c|c|c|}
\hline Time (hr): & $-\frac{1}{4}$ & $-\frac{1}{2}$ & 0 & 1 & 2 & 3 & 4 & 5 & 6 & 7 & 8 & 9 & 10 & 11 & 12 \\
\hline $\begin{array}{l}\text { Acromegalic patient } \\
\text { Case } 1 \\
\text { Case } 3\end{array}$ & 49 & $\begin{array}{r}80 \\
100\end{array}$ & $\begin{array}{r}49 \\
95 \\
125\end{array}$ & $\begin{array}{l}18 \\
45 \\
70\end{array}$ & $\begin{array}{l}18 \\
50 \\
90\end{array}$ & $\begin{array}{l}28 \\
60 \\
85\end{array}$ & $\begin{array}{l}26 \\
45 \\
90\end{array}$ & $\begin{array}{r}78 \\
105 \\
104\end{array}$ & $\begin{array}{r}82 \\
55 \\
102\end{array}$ & $\begin{array}{l}71 \\
40 \\
95\end{array}$ & $\begin{array}{l}83 \\
55 \\
90\end{array}$ & $\begin{array}{l}75 \\
95 \\
85\end{array}$ & $\begin{array}{r}29 \\
105 \\
80\end{array}$ & $\begin{array}{l}40 \\
85 \\
95\end{array}$ & $\begin{array}{l}60 \\
95 \\
95\end{array}$ \\
\hline
\end{tabular}


SERUM LH, FSH, PROLACTIN, AND CORTICOSTEROIDS

Serum $\mathrm{LH}$ and FSH levels were within the normal range (LH, 0.4-6.0 mU/ml; FSH 0.2-5.9 mU/ml) in the male acromegalics, whereas both females were postmenopausal with $\mathrm{LH}$ levels fluctuating from 5.9 to $14.4 \mathrm{mU} / \mathrm{ml}$ in one patient and from 5.6 to 28.3 in the other. Their FSH levels varied from 21.6 to $32.1 \mathrm{mU} / \mathrm{ml}$ and from 1.6 to $5.3 \mathrm{mU} / \mathrm{ml}$ respectively. The infusion of GH-RIH did not significantly alter the gonadotrophin levels in any of the patients. Similarly prolactin levels were within the normal range (up to $20 \mathrm{ng} / \mathrm{ml}$ ) and these remained uninfluenced by the infusion of GH-RIH. The female acromegalic patient on carbimazole had prolactin levels within the normal range. Levels of serum corticosteroids measured in one patient were not influenced by GH-RIH when compared to a control day, the normal circadian rhythm being maintained.

\section{PZ/GH-RIH}

Plasma growth hormone levels after a single subcutaneous injection in one patient of $500 \mu \mathrm{g}$ of $\mathrm{PZ} / \mathrm{GH}-\mathrm{RIH}$ are shown in table VI. Two other acromegalics (cases 1 and 3 ) received also the same dose subcutaneously at four-hourly intervals, and GH levels were followed for 12 hours in each patient. The preparation extended the action of GH-RIH to between four and five hours compared to between two and four hours when it was combined with arachis oil or $16 \%$ gelatin (Besser et al., 1974). Increasing the dose to $2 \mathrm{mg} \mathrm{PZ} / \mathrm{GH}-\mathrm{RIH}$ did not prolong its action any further.

\section{SIDE EFFECTS}

None of the patients suffered any adverse side effects during these studies. One acromegalic man spontaneously reported that his sweating was decreased during the infusion of GH-RIH but returned within a few hours after its cessation.

\section{Discussion}

We have previously reported that GH-RIH will suppress plasma GH, glucagon, and insulin levels in acromegalic patients during infusions lasting up to 150 minutes (Mortimer et al., 1974). It was important, therefore, to look at the effects of prolonged infusions of GH-RIH in acromegalic and diabetic patients over a time period which was representative of their normal daily activities in order to observe the effects and interactions of the changing hormonal levels. We have now shown that plasma GH was reduced by GH-RIH in each patient while the increases in $\mathrm{GH}$ associated with food ingestion and the paradoxical rise after oral glucose were suppressed. Urinary $\mathrm{GH}$ secretion was also greatly reduced. These data indicate that the pituitary secretion rate of $\mathrm{GH}$ had been reduced and that the reduction was maintained as long as the infusion continued.

Serum somatomedin levels were reduced in one of the patients during the infusion of GH-RIH with a rebound after the infusion stopped. Presumably the GH levels were not suppressed to low enough levels for a sufficiently long time to exert the same effect on somatomedin in the other subjects. Plasma glucagon levels were also suppressed throughout the infusion and in response to a normal lunch in all the patients. In the three subjects in whom plasma insulin levels could be measured, however, clear breakthrough secretion of the hormone, though delayed, occurred both in response to lunch and after an oral glucose load. This was encouraging since our initial studies showing impaired insulin secretion after acute GH-RIH administration suggested that the precipitation or exacerbation of diabetes mellitus might become a serious problem during long term GH-RIH therapy. Though basal glucose levels tended to be higher in three subjects when GH-RIH was being infused the plasma glucose peaks after oral glucose were the same or lower in three patients, and only higher by $9 \mathrm{mg} / 100 \mathrm{ml}$ in the other. The patient with diabetes mellitus on chlorpropamide had much improved glucose tolerance. Though the patient with diabetes mellitus on soluble insulin had increased basal plasma glucose levels when receiving GH-RIH the peak level was not significantly increased during his G.T.T. or food when compared to the control studies. This occurred despite receiving only one-third of his normal insulin dose. Improvement in circulating glucose levels, therefore, probably depends on the degree of suppression of $\mathrm{GH}$ and glucagon since breakthrough secretion of insulin occurs. Further studies in patients with clinical diabetes mellitus without acromegaly are being performed to see if the suppression of plasma $\mathrm{GH}$ and glucagon levels results in better control of carbohydrate metabolism.

In the patient treated with carbimazole slightly raised basal TSH levels were clearly suppressed during the infusion of GH-RIH. Since the TSH response to exogenous synthetic TRH is also inhibited it seems likely that in this patient GH-RIH was preventing the action of endogenously secreted TRH on the pituitary thyrotrophs. This suggests that tonic TRH secretion by the hypothalamus plays an important role in maintaining TSH secretion and thyroidal homoeostasis and that control is not solely mediated at the pituitary level. The serum prolactin levels in this patient were within the normal range despite raised TSH levels and were unaffected by GH-RIH. It will be important, therefore, to monitor thyroid function test results carefully in patients being treated with long-term GH-RIH in order to detect and prevent the occurrence of hypothyroidism. All the hormones which were suppressed during the infusion showed a rapid rebound after the infusion had stopped, often to levels higher than during the preinfusion period. Sampling was not continued for long enough after the infusions to estimate whether the definite suppression of the release of hormones by GH-RIH was also associated with any inhibition of synthesis, but the marked and immediate rebound after the end of the infusions suggests that any such inhibition is not necessarily a dominant feature over a period of 28 hours. The pituitary hormones LH, FSH, prolactin, and ACTH (as reflected by serum corticosteroid levels) were not affected.

The combination of $500 \mu \mathrm{g}$ of GH-RIH with protamine zinc resulted in partial suppression of GH levels for up to five hours, in contrast to the effect of such a preparation in rats, which acts for 12 to 16 hours (Brazeau et al., 1974). Longer-acting preparations or analogues less susceptible to destruction in the circulation, however, will be required before long-term therapy of acromegaly and diabetes mellitus with GH-RIH becomes a practicable proposition. Work is continuing rapidly in this direction and such preparations should be available for clinical use in the near future. It should then be possible to exploit the extremely promising properties of this inhibiting hormone.

We thank the staff of the metabolic ward of St. Bartholomew's Hospital for their invaluable help during these studies; Mr. P. Sanders and the staff of the department of chemical pathology for the measurement of plasma glucose levels and routine biochemical investigations; and Mr. C. Baum for the measurement of serum corticosteroids. Dr. P. Sönksen very kindly provided the reagents for the insulin assays and Dr. H. Friesen the human prolactin used as standard. These studies were supported by the Joint Research Board of St. Bartholomew's Hospital, the Peel Medical Research Trust, and the Medical Research Council. Dr. A. S. McNeilly is in receipt of a grant from the Wellcome Foundation. Dr. S. R. Bloom has an M.R.C. Clinical Fellowship and is also supported by the British Diabetic Association.

Requests for reprints should be addressed to Professor G. M. Besser, St. Bartholomew's Hospital, London EC1A 7BE.

\section{References}

Alberti, K. G. M. M., et al. (1973). Lancet, 2, 1299 Baum, C. K., Tudor, R., and Landon, J. (1974). Clinical Chimica Acta.

In press. 
Bloom, S. R. (1971). Diabetologia, 7, 472.

Brazeau, P., et al. (1974). Endocrinology, 94, 184.

British Pharmacopoea. (1973). p. 246. London, H.M.S.O.

Coy, D. H., et al. (1973). Biochemical and Biophysical Research Communications, 54, 1267.

Forsyth, I. A., et al. (1971). British Medical fournal, 3, 225.

Hall, K. (1971). Acta Endocrinologica, 66, 491.

Hall, R., et al. (1973). Lancet, 2, 581 .

Hanssen, K. F. (1972). Acta Endocrinologica, 71, 665
Hansen, Aa. P., et al. (1973). British Medical fournal, 3, 523.

Mortimer, C. H., et al. (1973). Clinical Endocrinology, 2, 317.

Mortimer, C. H., et al. (1973). Clinical Endocrino

Mortimer, C. H., et al. (1974). Lancet, $2,697$.
McNeily, A. S. (1973). Proceedings of the Royal Society of Medicine, 66, 863.
Siler, T. M., et al. (1973). Fournal of Clinical Endocrinology and Metabolism, 37, 632 . Siler, T. M., et al. (1974). Fournal of Clinical Endocrinology and Metabolism,

Sönksen, P. H., et al. (1973). Clinical Science and Molecular Medicine, 45, 633.

\title{
Azathioprine in Ulcerative Colitis: Final Report on Controlled Therapeutic Trial
}

\author{
D. P. JEWELL, S. C. TRUELOVE
}

British Medical fournal, 1974, 4, 627-630

\section{Summary}

Eighty patients, all of whom were suffering from a frank clinical attack of ulcerative colitis, were admitted to the trial. The attack was treated with a standard course of corticosteroids and the patients were immediately placed on treatment with either azathioprine in a dose of $2.5 \mathrm{mg} / \mathrm{kg}$ body weight or dummy tablets. The trial tablets were continued for one year while the patients were maintained under regular clinical, sigmoidoscopic, histological, haematological, and biochemical surveillance. If a patient relapsed during such maintenance treatment he or she was treated with a further course of corticosteroids without interrupting maintenance treatment.

In the treatment of an actual attack of ulcerative colitis the results in the attacks which brought the 80 patients into the trial show that no benefit came from the addition of azathioprine to a standard course of corticosteroid therapy.

Patients admitted in their first attack of ulcerative colitis showed no benefit from the one-year maintenance treatment with azathioprine, the benefits of which were confined to patients admitted in a relapse of established disease. Even in these the difference between the treated group and the control group failed to reach statistical significance, but the difference was big enough to suggest that there is a prima facie case for regarding azathioprine as of some benefit in this group of patients.

\section{Introduction}

In an interim report we dealt with the results obtained in $\mathbf{4 0}$ patients with ulcerative colitis treated in a controlled therapeutic trial of azathioprine for one year (Jewell and Truelove, 1972). We admitted a further 40 patients to the trial and report here the clinical results for the whole group of 80 patients.

\section{Patients}

All the patients had classical ulcerative colitis. The diagnosis

\footnotetext{
Nuffield Department of Clinical Medicine, The Radcliffe Infirmary, Oxford

D.P. JEWELL, D.PHIL., M.R.C.P., Senior Medical Registrar (Present address: Department of Medicine, Royal Free Hospital, London WC1X 8LF) S. C. TRUELOVE, M.D., F.R.C.P., Consultant Physician
}

was made on the basis of a history of bloody diarrhoea coupled with sigmoidoscopic evidence of diffuse inflammation, biopsy evidence of an inflammatory reaction compatible with ulcerative colitis, and changes of ulcerative colitis on the barium enema film.

All patients had a frank attack of the disease on admission to the trial. Some were in their first attack of the disease, and others were suffering from a relapse of established disease. It was explained to the patients that a new treatment was being tested and they were free to volunteer to be included. The necessity for repeated attendances and serial sigmoidoscopic examinations with biopsy was included in the explanation. Married women of fertile age were advised to avoid conception during the trial.

\section{Experimental Design}

A two-by-three stratified design was used. Patients were treated initially as either inpatients or outpatients depending on an overall clinical assessment of the severity of their attack. They were also subdivided according to the length of history into three categories: first attack; short history (less than five years); and long history (more than five years). As a result of this double specification patients fell into six groups.

Within each of these groups patients were allotted at random to real or dummy azathioprine treatment, a system of restricted randomization being used so that each block of six patients contained three on azathioprine and three on dummy tablets. The trial treatment was prescribed as "azathioprine special," and the hospital pharmacists worked from a master sheet indicating whether a particular patient was to be given real or dummy azathioprine.

The attack which brought the patient into the trial was treated with a standard course of corticosteroids together with general medical measures in the case of the inpatients. The regimen of corticosteroid treatment for outpatients was oral prednisolone $5 \mathrm{mg}$ four times a day and prednisolone disodium retention enemata nightly. If the therapeutic response was good this regimen was maintained for one month and then tailed-off.over the next two weeks.

As the attack was severe in all inpatients treatment began with a five-day intensive course of intravenous therapy as follows: nothing by mouth except water, intravenous control of water and electrolyte balance, prednisolone 21-phosphate $40 \mathrm{mg}$ daily in the intravenous fluid, tetracycline $1 \mathrm{~g}$ daily in divided doses in the intravenous fluid, and rectal drip of hydrocortisone hemisuccinate sodium $100 \mathrm{mg}$ twice daily. If the clinical response was good this was followed by resumption of feeding and oral prednisolone $40 \mathrm{mg}$ daily in divided doses. When discharged the patients were on the outpatient regimen and treatment was tailed-off after one month from the start of treatment. 